\title{
Detection and Determination of Bacillus cereus in Cooked Rice and Some Types of Spices with Ribosomal 16SrRNA gene Selected from Iraqi Public Restaurants
}

\author{
Ahmed Ibrahim Jessim*, Saad Sabah Fakhry and Samarah Jafar Alwash
}

Ministry of higher education, scientific research, science and technology. Food contamination research center. Baghdad, Iraq

\section{Corresponding Author}

Ahmed Ibrahim Jessim

e-mail: ahm_jas71@yahoo.com

\author{
Article History \\ Manuscript No. AR1814a \\ Received in 20 ${ }^{\text {th }}$ May, 2017 \\ Received in revised form $28^{\text {th }}$ May, 2017 \\ Accepted in final form $7^{\text {th }}$ June, 2017
}

\begin{abstract}
Spices can be considered as one of the sources of bacterial food pollution because of spices multiuse, in addition to the manufacturing processing and use, also they considered as one of food contamination reason due to the quantity of microorganisms like spore forming Bacteria such as Bacillus cereus. These road shape bacteria and its spores can move by air fast and easy, $B$. cereus is indicated to Diarrheal syndrome which linked to Non-hemolytic enterotoxin (NHE). Different kinds of 40 samples of spices was tested and 24 samples of cooked rice which considered as traditional food for wide stratum of Iraqi people from public restaurants located in Baghdad city, spices samples continued high number of $B$. cereus in spice (Fennel) in high number about $44 \times 10^{5} \mathrm{Cfu} \mathrm{g}^{-1}$ in addition to sample of spice (Kebab) $39 \times 10^{5}$ $\mathrm{Cfu}^{\mathrm{g}-1}$ these numbers are high and unacceptable. As for samples of cooked rice have a fewer numbers of bacteria except one sample had record $4.9 \times 10^{3} \mathrm{Cfu} \mathrm{g}^{-1}$ in winter. But in summer samples had a higher numbers of $\mathrm{B}$. cereus than winter period, some samples continued $14.4 \times 10^{5}, 12.3 \times 10^{5}$ and $1.15 \times 10^{5} \mathrm{Cfu} \mathrm{g}^{-1}$, these numbers are high and in this case can cause the diarrheal syndrome. Due to morphological and biochemical studies, these isolates are belong to $B$. cereus. After proceeding molecular biology and Polymerase Chain Reaction (PCR) for Ribosomal 16SrRNA gene-specific for these isolates, where tests are positive for 15 isolates of 64 selected isolates from spices and cooked rice, results showed these isolates are toxigenic
\end{abstract}

Keywords: Bacillus cereus, enterotoxin, spices, non-hemolytic enterotoxin

\section{Introduction}

Bacillus cereus is a group of ubiquitous, facultative anaerobic, spore-forming, and gram-positive, rod shapes (Tallent et al., 2012). Widely, B. cereus disturbed in nature and contaminates all agricultural products, also isolated from animal hair, cereal crops, dust, vegetation, fresh water and sediments, although in several cases isolated from fish (ICMSF, 1996). So as to isolated from soils (Tallent et al., 2012). Motile bacteria, found in plant material, hay, raw and processed food, also found frequently in pasteurized milk, causing spoilage because of the production of lipases and proteases (Torkar and Mozina, 2000). Two known types of diseases, Emetic and diarrheal, are caused by produced toxins by Bacillus cereus, an emetic caused by single heat -stable toxin, but the diarrheal, are caused by 3 or 4 heat-instable enterotoxins (Wijnands et al., 2002; Ehling-Schulz et al., 2005). It's an emetic cases characterized by vomiting after a few hours from ingested contaminated food. In the diarrhoeal cases, the symptoms appear after 8 to 16 hour from ingestion as diarrhea accompanied with abdominal pain. Generally, both types of food-borne illness are relatively and do not more than 24 houres (Ehling-Schulz and Messelhausser, 2013). Emetic illness frequently is linked with raw foods such as starchy food of plant origin (such as rice, pasta, potatoes, pastries and vermicelli, in 95\% of emetic cases, caused by fried or cooked rice which contaminated by $B$. cereus (Jenson and Moir, 2003). Also spices have a number of Bacteria such as Bacillus can cause a variety of foodborne illnesses when the spiced food are refrigerated or when leftovers are stored for several days (Jenson and Moir, 2003; Agata et al., 2002). The impact being on public health risks happened when using these spices and herbs as an addition to ready-to-eat foods (Jacobs and Steffen, 2003). This is especially true for those that undergo little further processing after being added to these foods. Studies have shown that overall $3.0 \%$ of herbs and spices contained high counts of $B$. cereus (Granum and Lund, 2006). In modern studies, toxins related to illnesses which caused by $B$. cereus characterized at molecular level, where in diarrheal syndrome is linked to non-haemolytic enterotoxin (NHE), hemolytic enterotoxin $(\mathrm{HBL})$ and cytotoxin $\mathrm{K}$ (CytK) and that of emetic type results from action of cereulide (Ces) toxin (Desai and Varadaraj, 2009). Consumption of foods that contain more than $10^{4}$ spores or vegetative cells of $B$. cereus per gram may result 
in food poisoning (Lopes and Alippi, 2007; Pirttijarvi et al., 1999). Spores can germinate and multiply in humid, low acid foods, from $4-5{ }^{\circ} \mathrm{C}$ to $55^{\circ} \mathrm{C}$. However, strains able to multiply below $7{ }^{\circ} \mathrm{C}$, and strains able to multiply above $45^{\circ} \mathrm{C}$, are not a most common. Emetic $B$. cereus is presumably unable to grow and produce their toxin cereulide below $10^{\circ} \mathrm{C}$, or in the absence of oxygen (EFSA, 2005). The (ELISA) Enzyme linked immunosorbent Adsorbed, is an immunoreactions which can use in toxins detections, and these types is useful in certain strains of bacteria to detect toxins (Brychta et al., 2009). The genotypic and phenotypic heterogeneities of the genus Bacillus, evident already for a long time (Ash et al., 1993). Molecular biology researches confirms the isolates certainly, there is no doubt that these type of researches helps a lot to fix the data in gene banks, thus confirm differentiation among strains of toxic bacteria in food poisoning cases (Banerjee et al., 2011). This study aimed to determine toxigenic $B$. cereus in cooked rice, and associated with common spices to understand which represent as traditional Iraqi food and if can cause harm to the consumers.

\section{Materials and Methods}

\subsection{Spices samples}

A different types of spices were collected from local Iraqi markets at Baghdad city, samples were rehydrated in sterilized glass bottles by adding sterilized distilled water, $500 \mu \mathrm{l}$ of spice suspension to $500 \mu$ l of Ethanol $\mathrm{C}_{2} \mathrm{H}_{6} \mathrm{O} 100 \%$ and preparing serial dilutions after 30 minutes of $\mathrm{C}_{2} \mathrm{H}_{6} \mathrm{O}$ exposure, the samples was cultured on Luria Bertani agar.

\subsection{Rice samples}

Along study period for two seasons' winter and summer of 2014, 48 samples are collected randomly from different public restaurants at Baghdad city. Then 10 grams of cocked rice weighted and put in continuers of normal saline, $500 \mu \mathrm{l}$ of suspension taken and mixed with $500 \mu$ of Ethanol $\mathrm{C}_{2} \mathrm{H}_{6} \mathrm{O}$ $100 \%$ for 30 minutes, and preparing serial dilutions after 30 minutes of $\mathrm{C}_{2} \mathrm{H}_{6} \mathrm{O}$ exposure, the samples was cultured on Luria Bertani agar.

\subsection{Chemical and biochemical tests}

All isolates of Bacillus spp. from Spices and Cooked Rice were tested for catalase, motility, production of lecithinase, reduction of nitrate, the Voges-Proskauer reaction, tyrosinase activity, mannitol and arabinose utilization, anaerobic utilization of glucose, starch and gelatin hydrolysis, according to standard protocols (Gordon, 1981; Lancette and Harmon, 1980; Pirttijarvi, 2000). Isolates were tested for hydrolysis of lecithin after incubation in egg-yolk nutrient agar, to detect production of phosphate acetylcholine hydrolase (Van Netten and Kramer, 1992), and for haemolytic activity and production of a discontinuous haemolytic pattern on blood agar plates (Beecher and Wong, 1994). When necessary, API 50 CHB strips (Biomerieux $\mathrm{ux}^{\circledR}$ ) were used for further identification

\subsection{Extraction of chromosomal DNA from Bacillus}

A fresh colony of Bacillus spp. isolates is inoculated in $7 \mathrm{ml}$ of L. B. with a specific antibiotic then incubated overnight at 37
${ }^{\circ} \mathrm{C}$. After incubation, bacterial cells of Bacillus spp. centrifuged at $7000 \mathrm{rpm}$ for five minutes, the obtained pellets was washed with five $\mathrm{ml}$ of Lysis Buffer consisting of $50 \mathrm{mM}$ of EDTA and $0.1 \mathrm{M} \mathrm{NaCL}$ then centrifuged again and resuspended cells with $1 \mathrm{ml}$ of Lysis Buffer to which added $0.250 \mathrm{ml}$ of lysozyme, after that the mixture above is incubated for $10 \mathrm{~min}$. at $37^{\circ} \mathrm{C}$. Then we added $0.075 \mathrm{ml}$ of $20 \%$ Sarkosyl, stirred by vigorously and centrifuged at $1000 \mathrm{rpm}$ at $4{ }^{\circ} \mathrm{C}$ for $1 \mathrm{~min}$. then moved to precipitation of DNA by adding 0.1 volume of sodium acetate and 2.5 volumes of $2\left(\mathrm{CH}_{3}\right) \mathrm{O}$. Subsequently, the precipitated DNA was washed with $2\left(\mathrm{CH}_{3}\right) \mathrm{O} 70 \%$, and centrifuged again in same conditions above, the obtained pellets re-suspended in $500 \mu \mathrm{l}$ of sterilized deionized water. As previously described analysis is performed by electrophoresis in a 1.6\% Agarose gel

\subsection{Amplification and analysis of 16 SrRNA by PCR}

Primers U1 and U2 described by (Ash et al., 1993), which used for PCR amplification of the 16SrRNA (Lynn et al., 2013), from $B$. cereus Isolates of both spices and Cooked Rice. They are derived from conserved regions amplifying a DNA fragment of about $1.1 \mathrm{~kb}$, of $16 \mathrm{SrRNA}$ genes from Bacillus spp. and closely related genera. PCR mixtures and amplifications were carried out as described previously (Alippi et al., 2002).

\section{Results and Discussion}

Spices are known to be contaminated with different microorganisms. Fennel and Kabab spices carried a high number of bacteria as $44.6 \times 10^{5}$ and $39.2 \times 10^{5} \mathrm{Cfu}^{-1}$ Curry, to a lesser extent, may also be infected $[25,26,27,10]$. Most of present bacteria in spices are aerobic spore-former kind of spices and number of bacteria was recorded as shown in Table 1.

\begin{tabular}{lc}
\hline Table 1: Kinds of spices and No. of B. cereus \\
\hline Common name & No. of bacteria Cfu mg-1 \\
\hline Cubeb & $2.0 \times 10^{5}$ \\
Cloves & $0.42 \times 10^{5}$ \\
Nutmeg & $1.4 \times 10^{5}$ \\
Black pepper & $14.0 \times 10^{5}$ \\
Cinnamon & $1.2 \times 10^{5}$ \\
Fennel & $44.6 \times 10^{5}$ \\
Cumin & $12.1 \times 10^{5}$ \\
Chili pepper & $11.3 \times 10^{5}$ \\
Turmeric & $2.7 \times 10^{5}$ \\
Curry & $22.5 \times 10^{5}$ \\
Biryani spices & $0.22 \times 10^{5}$ \\
Shawerma spices & $0.21 \times 10^{5}$ \\
Kabab spices & $39.2 \times 10^{5}$ \\
Bastirma spices & $0.38 \times 10^{5}$ \\
Dolma spices & $0.6 \times 10^{5}$ \\
\hline
\end{tabular}


One sample was chosen at my house as a control have no growth of bacteria, but when cooked with oil and salt after incubation $1.6 \times 10^{2} \mathrm{Cfu} \mathrm{g}^{-1}$ of bacteria, here may be boiled rice may will not reach growing of spores, and the counts of bacteria are shown in Table 2.
As well as in samples of cooked rice in this study, along study period from $26 / 01$ to $16 / 03 / 2014$, for samples contaminated with few number of $B$. cereus with one sample somehow contaminated with high number of $B$. cereus, and for same reason one sample was chosen as control the boiled one

Table 2: No. of B. cereus cells in cooked rice samples collected along study period from 26/01-16/03/2014

\begin{tabular}{lllc}
\hline Sampling date & Sampling place & Type of sample & No. of bacteria Cfu g-1 \\
\hline $26 / 01 / 2014$ & House & Uncooked rice & N. G \\
$26 / 01 / 2014$ & House & Cooked rice & $1.6 \times 10^{2}$ \\
$26 / 01 / 2014$ & Al Radhwanieya public restaurant & Cooked rice & N. G \\
$26 / 01 / 2014$ & Al Bayaa near wholesale markets & Cooked rice & $4 \times 10^{2}$ \\
$26 / 01 / 2014$ & Restaurant at Al Bayaa near the garage & Cooked rice & $2 \times 10^{2}$ \\
$29 / 01 / 2014$ & Bab Al Muadham near the garage & Cooked rice & N. G \\
$02 / 02 / 2014$ & Bab Al Sharqi near the public garage & Cooked rice & $3 \times 10^{2}$ \\
$22 / 02 / 2014$ & Jihad Neighborhood restaurant market & Cooked rice & N. G \\
$22 / 02 / 2014$ & Al Eskan & Cooked rice & N.G \\
$22 / 02 / 2014$ & Police tunnel (Nafakh alshurta) & Cooked rice & $23 \times 10^{2}$ \\
$09 / 03 / 2014$ & Near Al Andalus Plaza & Cooked rice and vermicelli & $3.2 \times 10^{2}$ \\
$09 / 03 / 2014$ & Al Karrada Dakhel near Abbas Mustafa mosque & Cooked rice & $1.2 \times 10^{2}$ \\
$09 / 03 / 2014$ & Al Karrada Dakhel near old Alawrzde & Cooked rice and vermicelli & $0.8 \times 10^{2}$ \\
$09 / 03 / 2014$ & Al Karrada Kharej & Cooked rice & $4.6 \times 10^{3}$ \\
$10 / 03 / 2014$ & Jihad Neighborhood on the public road & Cooked rice & $\mathrm{N} . \mathrm{G}$ \\
$16 / 03 / 2014$ & Jihad Neighborhood near market & Cooked rice and vermicelli & $1 \times 10^{2}$ \\
\hline $\mathrm{N}$ & &
\end{tabular}

${ }^{*}$ No growth

have no growth of bacteria, but the same sample that cooked with salt and oil, we count $10 \times 10^{2} \mathrm{Cfu} \mathrm{g}^{-1}$, as shown in Table 3 , thus mean, there were two reasons can effect growing of bacteria beside of temperature, salts and oil reached spores growing of bacteria, some highest numbers was because of adding spices to the food and ready food, in this case the first reason of food poisoning is belong to human beavers in food cooking and preparing.

On the other hand, for second period of study from 08/06 - 16/06 2014, due to worming and humidity, many samples of cooked rice contaminated heavily and carry number of bacteria $14.4 \times 10^{5} \mathrm{Cfu} \mathrm{g}^{-1}$ in sample of Al Eskan, $12.3 \times 10^{5} \mathrm{Cfu}$ $\mathrm{g}^{-1}$ in sample of Police Tunnel (Nafak Alshurta) and $1.15 \times 10^{4}$ $\mathrm{Cfu} \mathrm{g}^{-1}$ in the sample of Al Karrada Kharej as shown in Table 3.

Among all tested isolated species in this study, only a few of them have associated with food poisoning. Indeed, $B$. cerus recognized as the etiological agent of food poisoning outbreaks in Europe as far back as 1960 (Jenson and Moir, 2003). Black peeper contaminated with aerobic spore formers enormously increased the microbial count of meat like sausage. Aerobic spore formers also detected in Black peeper powder (Agata et al., 2002). According to (Paananen et al., 2002). The recorded results in Nafak Al shurta (Police tunnel), sample of Al eskan and Al Karrada Kharej. Samples, are near to make Emetic syndrome due to the recorded number of $B$. cereus. These results are unacceptable because will make food poisoning due to high number of $B$. cereus.

\subsection{Bacterial morphology, chemical and biochemical tests}

Morphological studies of vegetative cells and microscopic examination of spores also physiological and biochemical tests of the Bacillus spp. All isolates from spices and cooked rice are Gram positive, and catalase test is positive reaction, and hydrolyzed gelatin, and didn't produced acid from arabinose. Variable results obtained for lecithinase activity, V-P reaction, mannitol utilization, starch hydrolysis, tyrosinase activity and reduction of nitrate to nitrites. Haemolytic activity shown by $95 \%$ of the isolates, of these, $11 \%$ produced a discontinuous haemolytic pattern, which usually correlated with the presence of haemolysin BL (Beecher and Wong, 1994). All the isolates had ellipsoidal spores that occupied a central position without distention of the sporangium. None of the isolates presents a parasporal inclusions. A number of physiological and biochemical properties used to differentiate the Bacillus sp. recorded by other research groups (Seenappa and Kempton, 2008). They found a variation in biochemical as well as fermentative reactions particularly 


\begin{tabular}{|c|c|c|c|}
\hline Sampling date & Sampling place & Type of sample & No. of bacteria $\mathrm{Cfu} \mathrm{g}^{-1}$ \\
\hline 08/06/2014 & House & Non cooked rice & N. G* \\
\hline 08/06/2014 & House & Cooked rice & $10 \times 10^{2}$ \\
\hline 08/06/2014 & Al Bayaa near wholesale markets & Cooked rice & $5 \times 10^{2}$ \\
\hline 08/06/2014 & Restaurant at Al Bayaa near the garage & Cooked rice & $2.5 \times 10^{2}$ \\
\hline 08/06/2014 & Bab Al Muadham near the garage & Cooked rice & $7.5 \times 10^{2}$ \\
\hline 08/06/2014 & Bab Al Sharqi near the public garage & Cooked rice & $2.5 \times 10^{2}$ \\
\hline 08/06/2014 & Jihad neighborhood restaurant in market & Cooked rice & $2.5 \times 10^{2}$ \\
\hline 08/06/2014 & Al Eskan & Cooked rice & $14.4 \times 10^{5}$ \\
\hline 08/06/2014 & Police tunnel (Nafakh Alshurta) & Cooked rice & $12.3 \times 10^{5}$ \\
\hline $15 / 06 / 2014$ & Near Al Andalus Plaza & Cooked rice and vermicelli & $8 \times 10^{2}$ \\
\hline $15 / 06 / 2014$ & Al Karrada Dakhel near Abbas Mustafa mosque & Cooked rice & $3 \times 10^{2}$ \\
\hline $15 / 06 / 2014$ & Al Karrada Dakhel near old Alawrzde & Cooked rice and vermicelli & $2 \times 10^{2}$ \\
\hline $15 / 06 / 2014$ & Al Karrada Kharej & Cooked rice & $1.15 \times 10^{4}$ \\
\hline $15 / 06 / 2014$ & Jihad neighborhood on the public road & Cooked rice & $2.5 \times 10^{2}$ \\
\hline $15 / 06 / 2014$ & Jihad neighborhood near market & Cooked rice and vermicelli & $3 \times 10^{2}$ \\
\hline $16 / 03 / 2014$ & Jihad neighborhood near market & Cooked rice and vermicelli & $1 \times 10^{2}$ \\
\hline
\end{tabular}

*No growth

with maltose and millibiose. Distinct type of bimolecular being produced by them and perhaps in the present study, variation was observed with xylose and other sugars. This would clearly indicate that bacillus having specific phenotypic line. According to the above described methods, an isolated Bacillus strains, are identified for each strain separately with Ribosomal 16SrRNA gene-specific PCR, which allowed for seven strains (indicated in Figure 1) to be identified

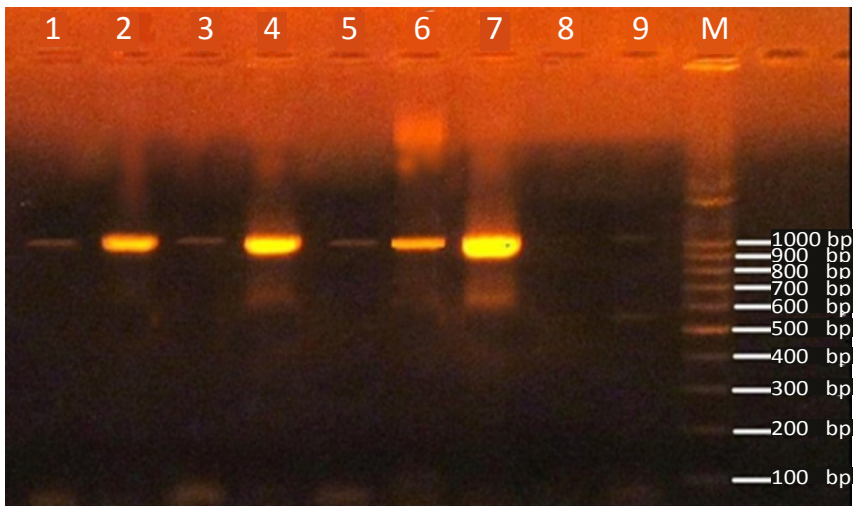

Figure 1: Representative PCR products showing amplicons of six B. cereus isolates. Lanes 1 molecular size marker 100. $\mathrm{M}=$ marker

subsequently as positive. Of the 64 isolates, 15 isolates are chosen for molecular characterization. Ten isolates were further characterized by PCR using $\mathrm{U} 1$ and $\mathrm{U} 2$ primer to identify up to species level. A characteristic banding pattern compare with molecular marker determined as $B$. cereus (Brychta et al., 2009; Beecher and Wong, 1994). From the group of Bacillus spp. now all can change the routine work in diagnosis and detection also go on by new methods of biomolecular to reach subtyping and risk-related strain profiling, due to the extreme intra-species diversity found in the genus Bacillus, DNA-based identification and typing methods are gaining increasing importance in routine diagnostics (EhlingSchulz et al., 2005), our results is near to several studies like (Ombui et al., 2008), which he described that the size marker from $475-500 \mathrm{bp}$. depending on primers were synthesized by Invitrogen ${ }^{\circledR}$ Co. USA at 2008 compared with our results which depending on primers were synthesized by Promega ${ }^{\circledR}$ Co. USA at 2014. As shown in Figure 1. The emetic endogenous gene of non-hemolytic enterotoxin (Nhe), described that gene size marker is $500 \mathrm{bp}$. the gene is same in B. cereus isolates from spices and rice, that mean, it may arrived in rice from spices by adding as flavors in rice during cooking or come from spiced chicken or meat due to spores behaviors which come grow in low temperature $\geq 6$ and worm temperature $\leq 55^{\circ} \mathrm{C}$ in manufactured and packed food (Pirttijarvi, 2000).

\section{Conclusion and recommendations}

Raw spices may contaminated with microbial pathogens, sometimes hold high numbers of bacteria, there are treatment and options of testing are available to reduce risks and to ensure food safety plans, always must be include information of ingredients, control of supply chain auditing suppliers, and planning for supply chain interruptions. Manufacturers 
of food must consider these programs to determine using of treated from untreated spice. For rice must treat it before using due to number of meals which consuming by individuals of populations, all of this is taken into account to design monitoring system with control system regime which can help to reduce food poisoning risk.

\section{References}

Tallent, S.F., Kotewicz, K.M., Strain, E.A., Bennett, R.W., 2012. Efficient Isolation and Identification of Bacillus cereus Group. Food Biological Contaminants. Journal of AOAC International 95(2), 446-451.

ICMSF, International Commission on Microbiological Specifications for Foods (1996). Bacillus cereus. In: Roberts, T.A., Baird-Parker, A.C., Tompkin, R.B. (Eds.), Micro-organisms in Foods 5 Microbiological Specifications of Food Pathogens, Blackie Academic and Professional, London, 20-35.

Torkar, T.K., Mozina, S.S., 2000. Differentiation of Bacillus cereus Isolates from Milk and Milk Products with Biochemical, Immunological, AP-PCR and PCR-RFLP Methods. Original scientific paper. Food technol. Biotechnol 38(2), 135-142.

Wijnands, L.M., Dufrennne, J.B., van Leusden, F.M., 2002. The pathogenic mechanism of the diarrhoeal syndrome caused by Bacillus cereus. The National Institute for Public Health and the Environment (RIVM), Bilthoven, the Netherlands.

Ehling-Schulz, M., Svensson, B., Guinebretiere, M-H., ck, T.L., Andersson, M., Schulz, M., Fricker, M., Christiansson, A., Granum, P.E., Martlbauer, E., Nguyen-The, C., SalkinojaSalonen, M., Scherer, S., 2005. Emetic toxin formation of Bacillus cereus is restricted to a single evolutionary lineage of closely related strains. Microbiology 151, 183-197.

Ehling-Schulz, M., Messelhäusser, E., 2013. Bacillus "next generation" diagnostics: moving from detection toward sub typing and risk-related strain profiling. Frontiers in Microbiology. Food Microbiology 4(32), 1-8.

Jenson, I., Moir, C.J., 2003. Bacillus cereus and other Bacillus species. In: Hocking AD (Ed) Foodborne Microorganisms of Public Health Significance. 6th edition, pp445-478. Australian Institute of Food Science and Technology Inc., NSW Branch.

Agata, N., Ohta, M., Yokoma, K., 2002. Production of Bacillus cereus emetic toxin (cereulide) in various foods. International Journal of Food Microbiology 73, 23-27.

Jacobs Jr, D.R., Steffen, L.M., 2003. Nutrients, foods, and dietary patterns as exposures in research: a framework for food synergy ${ }^{1-3}$. American Society for Clinical Nutrition 78(suppl), 508S-13S.

Granum, P.E., Lund, T., 2006. Bacillus cereus and its food poisoning toxins. FEMS Microbiology Letters 157, 223-228.

Desai, S.V., Varadaraj, M.C., 2009. Prevalence of toxigenic traits in native food isolates of Bacillus cereus in the city of Mysore, Southern India. Journal of Microbiology and Antimicrobials 1(2), 27-34.

Lopes, A.C., Alippi, A.M., 2007. Phenotypic and genotypic diversity of Bacillus cereus isolates recovered from honey. International Journal of Food Microbiology. ELSEVIER 117(2), 175-184.

Pirttijarvi, T.S.M., Andersson, M.A., Scoging, A.C., SalkinojaSalonen, M.S., 1999. Evaluation of methods for recognizing strains of the Bacillus cereus group with food poisoning potential among industrial and environmental contaminants. Syst. Appl. Microbiol 22, 133-144.

EFSA, 2005. Opinion of the Scientific Panel on Biological Hazards on Bacillus cereus and other Bacillus spp. in foodstuffs. The EFSA Journal 175, 1-48.

Brychta, J., Smola, J., Pipek, P., Ondracek, J., Bednar, V., Cizek, A., Brychta, T., 2009. The Occurrence of Enterotoxigenic Isolates of B. cereus in Foodstuffs 27(4), 284-292.

Ash, C., Priest, F.G., Collins, M.D., 1993. Molecular identification of rRNA group 3 bacilli (Ash, Farrow, Wallbanks and Collins) using a PCR probe test. Proposal for the creation of a new genus Paenibacillus. Antonie Leeuwenhoek J. Microbiol 64, 253-260.

Banerjee, M., Nair, G.B., Ramamurthy, T., 2011. Phenotypic $\&$ genetic characterization of Bacillus cereus isolated from the acute diarrhoeal patients. Indian J Med Res. 133, 85-95.

Gordon, R.E., 1981. One hundred and seven years of the genus Bacillus. In Berkeley, R.C., Goodfellow, M. (Ed,), The aerobic endosporeforming bacteria. Academic Press. London, 1-15.

Lancette, G.A., Harmon, S.M., 1980. Enumeration and confirmation of Bacillus cereus in foods: collaborative study. Journal of the Association of Official Analytical Chemists 63, $581-586$.

Pirttijarvi, T., 2000. Contaminant Aerobic Sporeforming Bacteria in the Manufacturing Processes of Food Packaging Board and Food. University of Helsinki, 9-39.

Van Netten, P., Kramer, J. M., 1992. Media for the detection and enumeration of Bacillus cereus in foods: A review. International Journal of Food Microbiology 17, 85-99.

Beecher, D.J., Wong, A.C.L., 1994. Identification of Hemolysin BL-producing Bacillus cereus isolates by a discontinuous hemolytic pattern in blood agar. Appl. Environ. Microbiol 74, 1646-1651.

Lynn, T.M., Vijayalakshmi, G., Vanajakshi, V., 2013. Molecular Characterization of Enterotoxin Genes from Food-borne Pathogen, Bacillus cereus. Journal of Scientific and Innovative Research. India 2(1), 30-38. 
Alippi, A.M., Lopez, A.C., Aguilar, O.M., 2002. Differentiation of Paenibacillus larvae subsp. larvae, the cause of American Foulbrood of honeybees, by using PCR and restriction fragment analysis of genes encoding 16S rRNA. Applied and Environmental Microbiology 68, 3655-3660.

FAO, 2012. Microbiological Hazards in fresh vegetables and herbs.

Guarino, P.A., 1972. Microbiology Of spices, herbs and related material. Proceeding $7^{\text {th }}$ Annual symposium West New York State Institute of Food Technology, 16-18.

Mousumi, B. P., 1972. Microbiological quality of some retail spices in India Food Research International 36, 469-474.

Paananen, A., Mikkola, R., Sareneva, T., Matikainen, S., Hess,
M., Anderrson, M., Julkunen, I., Salkinoja-Salonen, M.S., 2002. Inhibition of human natural killer cell activity by cereulide, an emetic toxin from Bacillus cereus. Clinical and Experimental Immunology 129, 420-428.

Seenappa, M., Kempton, A.G., 2008. A Note on the Occurrence of Bacillus cereus and Other Species of Bacillus in Indian Spices of Export Quality. Journal of Applied Bacteriology 50(2), 225-228.

Ombui, J.N., Ndhiu Gitahi, J., Gicher, M.M., 2008. Direct detection of Bacillus cereus enterotoxin genes in food by multiplex Polymerase Chain Reaction. International Journal of Integrative Biology 2(3), 172-181. 